\title{
Open Specification Data Format
}

National Cancer Institute

\section{Source}

National Cancer Institute. Open Specification Data Format. NCI Thesaurus. Code C85872.

A published specification for storing digital data that is freely distributed and available to be used and implemented by anyone. 